\title{
MEASURING THE EFFICIENCY IN LENDING OPERATIONS OF STATE CO-OPERATIVE BANKS IN INDIA
}

\author{
Devi Sekhar $\mathrm{R}^{1}$, Dr. Sony Vijayan ${ }^{2}$ \\ ${ }^{1}$ Research Scholar, Department of Commerce and Management, Amrita Vishwa Vidyapeetham (Deemed to be University), Kochi. \\ ${ }^{2}$ Associate Professor, Department of Commerce and Management, Amrita Vishwa Vidyapeetham (Deemed to be University),
} Kochi.

\begin{abstract}
Co-operatives are member driven and democratic in nature and played a pioneering role in providing agricultural credit to a very large rural population, especially in remote areas. The State Cooperative Banks (SCBs) are the apex level co-operative credit institutions and play a significant role in the functioning and growth of the co-operative credit structure in the respective states. Financial assistance from Reserve Bank of India and National Bank for Agriculture and Rural Development (NABARD) are mainly routed through the state co-operative banks and hence they have to ensure efficiency in their lending operations. The study has used the benchmarking technique DEA and revealed higher deviations in efficiency scores among state co-operative banks. The problems and challenges of SCBs differ from state to state. Hence in every state, the management and the regulating authorities should work on transforming the co-operative credit system into a viable and self- sustaining system by identifying and addressing their core inefficiencies.
\end{abstract}

Keyword: Co-operative Bank, Efficiency, Data Envelopment Analysis.

\section{Introduction}

Co-operatives were formed during the last decades of $19^{\text {th }}$ century to address the issues of indebtedness, famine, poverty and social unrest in rural India. The industrial revolution had made conventional agriculture and cottage industries uneconomic and the middlemen started exploiting the small producers. At that period the farmers and rural population found the co-operatives an attractive measure for making small savings and utilize the same for collectively solving the common problems relating to credit, availability of inputs and marketing of agricultural produce. The International Cooperative Alliance (ICA) has put forward a reconsidered and revised set of co-operative principles in view of the political, social, economic and technical changes that taking place all over the world. Thus, according to ICA the seven co-operative principles are "voluntary and open membership, democratic member control, members' economic participation, autonomy and independence, education, training and information, cooperation among co-operatives and concern for community".

Rural Co-operatives in India are classified into two segments; one for meeting short-term and medium- term credit requirements and the other for long term loans. The short-term structure is again classified into two-tier and three-tier (fig. No.1). In larger states, District Co-operative Banks (DCBs) or Central Co-operative Banks form a link between Primary Agricultural Credit Societies and the respective State Cooperative Bank. According to National Federation of State Cooperative Banks (NAFSCOB) as on $31^{\text {st }}$ March 2018, 19 states in India have a three-tier short-term co-operative credit structure while 14 states and union territories have a two-tier co-operative credit structure.

\section{State Co-operative Bank}

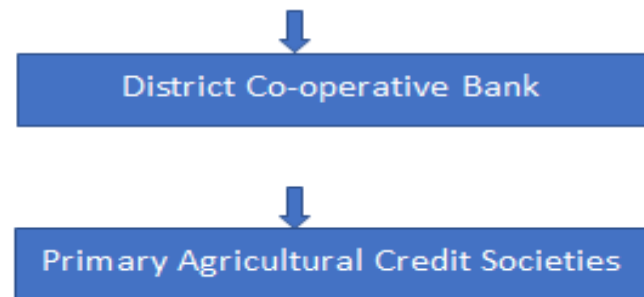

A three tier Structure

\section{A two tire Structure}

Fig. No.1; Short Term Co-operative Credit Structure

The State Co-operative Banks (SCBs) are the apex level cooperative credit institutions and play a significant role in the

functioning and growth of the co-operative credit structure in the respective states. But they are facing tough competitions 
and challenges in adapting to the rapid changes in the banking sector. They act as the supervisors and have to ensure effective internal control and risk management in lower tiers. In the two-tier structure, the credit needs of PACS have to be directly met by the SCBs and need to perform the supervision of PACS. Both RBI and NABARD monitor the functioning of SCBs and they are also under the purview of the respective State Co-operative Societies Act. The major function of the SCBs are lending to the lower tiers and hence, in the paper the main focus is their efficiency in lending operations. As the functions of SCBs differ widely with that of commercial banks, we find it more appropriate to conduct a comparative study of SCBs among themselves.

\section{Efficiency}

The term efficiency is defined as "the ratio of observed to maximum potential output obtainable from the given input, or the ratio of the minimum potential to observed input required to produce the given output, or some combination of the two" (Lovell, 1993). The first ratio is for an output oriented or an output maximization approach and the second part is for an input oriented or input minimization approach. The efficiency measure thus obtained is relative to an optimal value. There are two types of production frontiers; deterministic or stochastic. For deterministic models, it is assumed that an exact value of maximum output possible is obtained from a given level of inputs while in stochastic model the value of output gets affected by randomness. But in both cases the distance of observations from the frontier is measured. In stochastic model, the frontier is assumed at the initial stage while in deterministic the frontier is obtained from the analysis result. To measure efficiency, the most widely accepted tools are Stochastic Frontier Analysis under Stochastic Approach (SFA) and Data Envelopment Analysis (DEA) under deterministic approach. Farrell in 1957 has put forward the measure of efficiency by comparing it with an empirical frontier and this form the basis for both DEA and SFA. Measuring efficiency with parametric approaches demand prior assumption of the functional form that gives the shape of the frontier and the associated behaviour. Any error on this assumption will alter the values of efficiency and therefore the parametric techniques are subjected to specification errors. The non-parametric techniques do not impose prior assumption on the functional form of the frontier, but they are not taking into account the random errors (errors in data, error owing to luck, measurement errors etc.).

\section{Literature Review}

In 1997, Berger and Humphrey critically reviewed 130 studies that applied various method for efficiency measurements and found that "the established approaches to efficiency measurement differ primarily in how much shape is imposed on the frontier and the distributional assumptions imposed on the random error and inefficiency". The study could not reach into a consensus regarding the best technique for efficiency estimation rather it suggests for choosing techniques by addressing their limitations. (Gaurav \& Krishnan, 2017) conducted an efficiency analysis of District co-operative Banks from 2002 to 2014 using DEA and SFA. It considered investments and advances as outputs, while the inputs are deposits, share capital, borrowings, reserves and Cost of Management (COM) per employee. The paper found considerable variation in efficiency scores depending upon whether investment has chosen as output or advances as output.

(Rakshit \& Chakrabarti, 2012) have conducted a study on the factors influencing the financial performance of apex cooperative banks with special reference to the West Bengal Cooperative Bank and found that the loans and advances have a negative impact on the net income of the bank. The study emphasized the need for efficient utilization of low-cost funds. (Roy \& Das, 2013) conducted a study on the cost and revenue efficiency of State Co-operative banks in India with special reference to north eastern region using DEA. The findings indicate considerable level of inefficiency among SCBs in north eastern region. The study also compared the cost and revenue efficiency of SCBs before and after the revamping package of Vaidyanathan Committee and found significant increase in the efficiency scores after the revamping package. Ganesan (2006) analysed the performance and operational efficiency of State Co-operative Banks in India using data envelopment analysis. The inputs considered are membership, labour, number of branches and borrowings, while the outputs are advances and investments. The results indicate that the efficiency of south and west state co-operative banks is better than those in south and north east region.

\section{Methodology}

The studies on apex co-operative banks in India are very limited and we could not find any literatures on their efficiency in lending operations. An empirical study is conducted among the 32 State Co-operative Banks in India based on the secondary data from National Federation of State Co-operative Banks (NAFSCOB) and websites of the banks. Discussions were also undertaken with various officials and experts in the co-operative banking sector. The Variables are selected based on the Intermediation Approach for measuring banking efficiency. The inputs considered are share capital, total deposits, reserves and borrowings while the output is loans \& advances. In a three-tier structure, share capital of SCBs are mainly contributed by DCBs, while in a two-tier structure by PACS. Many of the State Governments also infuse capital in the respective state co-operative banks.

The data obtained are cross sectional data as on $31^{\text {st }}$ March during the years 2016,2017 and 2018.

\section{Analysis and Discussion}

ISSN (Print): 2204-0595

ISSN (Online): 2203-1731 
The efficiency scores were computed using the non-parametric data envelopment analysis. Since the focus of the paper is the efficiency in lending operations an output-oriented approach is adopted. That is the maximization of efficiency in lending operations. The technical efficiency based on Constant Return to Scale, Variable Return to Scale and Scale efficiency are computed for three years and results are shown in Table No.1. The State Co-operative Banks from Bihar, Goa, Pondicherry,
Punjab, Uttarakhand, and West Bengal are found to be more efficient in lending operations in comparison to their peers in other states in all the three financial years. It means they are able to grant more loans and advances from the given level of inputs. In the financial year 2017-18, Andaman and Nicobar, Assam, Chandigarh, Himachal Pradesh, Tripura and Assam are found to be less efficient. Andaman and Nicobar, Sikkim and Tripura are less efficient in the Financial year 2016-17.

Table No.1. Efficiency Scores of the State Co-operative Banks

\begin{tabular}{|c|c|c|c|c|c|c|c|c|c|c|}
\hline Sl. & $\begin{array}{l}\text { States Co-operative } \\
\text { Banks }\end{array}$ & $\begin{array}{l}\text { CRS } \\
2018\end{array}$ & $\begin{array}{l}\text { VRS } \\
2018\end{array}$ & $\begin{array}{l}\text { Scale } \\
2018\end{array}$ & $\begin{array}{l}\text { CRS } \\
2017\end{array}$ & $\begin{array}{l}\text { VRS } \\
2017\end{array}$ & $\begin{array}{l}\text { Scale } \\
2017\end{array}$ & $\begin{array}{l}\text { CRS } \\
2016\end{array}$ & $\begin{array}{l}\text { VRS } \\
2016\end{array}$ & $\begin{array}{l}\text { Scale } \\
2016\end{array}$ \\
\hline 1 & Andaman and Nicobar & 0.218 & 0.228 & 0.955 & 0.124 & 0.133 & 0.929 & 0.148 & 0.154 & 0.964 \\
\hline 2 & Andhra Pradesh & 1.000 & 1.000 & 1.000 & 1.000 & 1.000 & 1.000 & 0.858 & 0.873 & 0.984 \\
\hline 3 & Arunachal Pradesh & 0.420 & 1.000 & 0.420 & 0.605 & 1.000 & 0.605 & 1.000 & 1.000 & 1.000 \\
\hline 4 & Assam & 0.096 & 0.167 & 0.576 & 0.450 & 0.588 & 0.765 & 0.574 & 0.629 & 0.914 \\
\hline 5 & Bihar & 1.000 & 1.000 & 1.000 & 1.000 & 1.000 & 1.000 & 1.000 & 1.000 & 1.000 \\
\hline 6 & Chandigarh & 0.117 & 0.443 & 0.263 & 1.000 & 1.000 & 1.000 & 0.976 & 1.000 & 0.976 \\
\hline 7 & Chhattisgarh & 0.313 & 0.314 & 0.997 & 0.365 & 0.366 & 0.997 & 0.404 & 0.413 & 0.978 \\
\hline 8 & Delhi & 0.842 & 0.855 & 0.985 & 0.931 & 0.938 & 0.992 & 0.703 & 0.704 & 0.999 \\
\hline 9 & Goa & 1.000 & 1.000 & 1.000 & 1.000 & 1.000 & 1.000 & 1.000 & 1.000 & 1.000 \\
\hline 10 & Gujarat & 1.000 & 1.000 & 1.000 & 1.000 & 1.000 & 1.000 & 0.739 & 0.742 & 0.997 \\
\hline 11 & Haryana & 0.877 & 0.896 & 0.979 & 0.886 & 0.893 & 0.992 & 0.774 & 0.779 & 0.994 \\
\hline 12 & Himachal Pradesh & 0.142 & 0.196 & 0.722 & 0.166 & 0.278 & 0.598 & 0.234 & 0.306 & 0.764 \\
\hline 13 & Jammu \& Kashmir & 0.580 & 0.868 & 0.668 & 1.000 & 1.000 & 1.000 & 1.000 & 1.000 & 1.000 \\
\hline 14 & Karnataka & 0.494 & 0.531 & 0.930 & 0.561 & 0.636 & 0.882 & 0.533 & 0.605 & 0.882 \\
\hline 15 & Kerala & 0.734 & 0.872 & 0.841 & 1.000 & 1.000 & 1.000 & 0.945 & 0.973 & 0.972 \\
\hline 16 & Madhya Pradesh & 0.688 & 0.740 & 0.930 & 0.827 & 0.988 & 0.837 & 1.000 & 1.000 & 1.000 \\
\hline 17 & Maharashtra & 0.590 & 0.889 & 0.664 & 0.518 & 1.000 & 0.518 & 0.673 & 0.970 & 0.693 \\
\hline 18 & Manipur & 0.582 & 0.883 & 0.660 & 0.496 & 1.000 & 0.496 & 0.698 & 1.000 & 0.698 \\
\hline 19 & Meghalaya & 1.000 & 1.000 & 1.000 & 0.839 & 0.996 & 0.843 & 1.000 & 1.000 & 1.000 \\
\hline 20 & Mizoram & 0.684 & 0.727 & 0.941 & 0.819 & 0.829 & 0.987 & 1.000 & 1.000 & 1.000 \\
\hline 21 & Nagaland & 0.905 & 1.000 & 0.905 & 1.000 & 1.000 & 1.000 & 1.000 & 1.000 & 1.000 \\
\hline 22 & Orissa & 1.000 & 1.000 & 1.000 & 1.000 & 1.000 & 1.000 & 0.747 & 0.888 & 0.841 \\
\hline 23 & Pondicherry & 1.000 & 1.000 & 1.000 & 1.000 & 1.000 & 1.000 & 1.000 & 1.000 & 1.000 \\
\hline
\end{tabular}




\begin{tabular}{|l|l|l|l|l|l|l|l|l|l|l|}
\hline 24 & Punjab & 1.000 & 1.000 & 1.000 & 1.000 & 1.000 & 1.000 & 1.000 & 1.000 & 1.000 \\
\hline 25 & Rajasthan & 0.762 & 0.765 & 0.996 & 0.870 & 0.900 & 0.966 & 0.974 & 1.000 & 0.974 \\
\hline 26 & Sikkim & 0.163 & 0.179 & 0.909 & 0.113 & 0.146 & 0.775 & 0.197 & 1.000 & 0.197 \\
\hline 27 & Tamil Nadu & 0.484 & 0.522 & 0.927 & 0.346 & 0.619 & 0.559 & 0.652 & 0.761 & 0.857 \\
\hline 28 & Telangana & 0.639 & 0.652 & 0.982 & 0.550 & 0.550 & 0.999 & 0.493 & 0.495 & 0.997 \\
\hline 29 & Tripura & 0.196 & 0.199 & 0.984 & 0.170 & 0.194 & 0.875 & 0.310 & 0.332 & 0.933 \\
\hline 30 & Uttar Pradesh & 0.851 & 0.911 & 0.933 & 0.842 & 0.990 & 0.850 & 0.958 & 1.000 & 0.958 \\
\hline 31 & Uttarakhand & 1.000 & 1.000 & 1.000 & 1.000 & 1.000 & 1.000 & 1.000 & 1.000 & 1.000 \\
\hline 32 & West Bengal & 1.000 & 1.000 & 1.000 & 1.000 & 1.000 & 1.000 & 1.000 & 1.000 & 1.000 \\
\hline & Mean & .668 & .745 & .880 & .734 & .814 & .890 & .768 & .832 & .924 \\
\hline
\end{tabular}

\section{Data Source: Nafscob}

\section{Correlation Analysis}

The efficiency scores of lending operations have been compared with various other parameters using correlation analysis. The VRS scores are compared with the performance of the banks during the financial year 2017-18. The following findings are derived from the results.

1. Efficiency and Share Capital: We could not find any significant correlation between the estimated efficiency scores and the amount of share capital. But there exists a negative correlation with $\mathrm{P}$ value -.479 for efficiency scores and the volume of government stake.

2. Efficiency and Overdue: We could find a negative correlation between overdue and efficiency with $\mathrm{P}$ value -.653. A negative correlation with $\mathrm{P}$ value -.739 between NPA and Efficiency. Hence, higher level of overdues and NPA are one the main sources of inefficiencies that needed immediate attention.
3. Efficiency and Profit: We could find a significant but a very small correlation between Profit and efficiency. Co-operatives are more welfare-oriented institutions and hence more relevance should be given for correcting inefficiencies.

4. Efficiency and No. of branches: We could find a negative correlation between the number of branches and the efficiency scores. This could be because all branches are not operating to their optimum level.

\section{Ratio}

Credit to Deposit Ratio is measured by dividing the total deposits of individual banks by total loans \& advances. The values are for the financial year 2017-18. Punjab and Andhra Pradesh have a very high $\mathrm{CD}$ ratio in percentage of above $300 \%$ while for Chandigarh, Jammu and Kashmir, Manipur, Sikkim and Tripura have got CD ratio of less than $10 \%$.

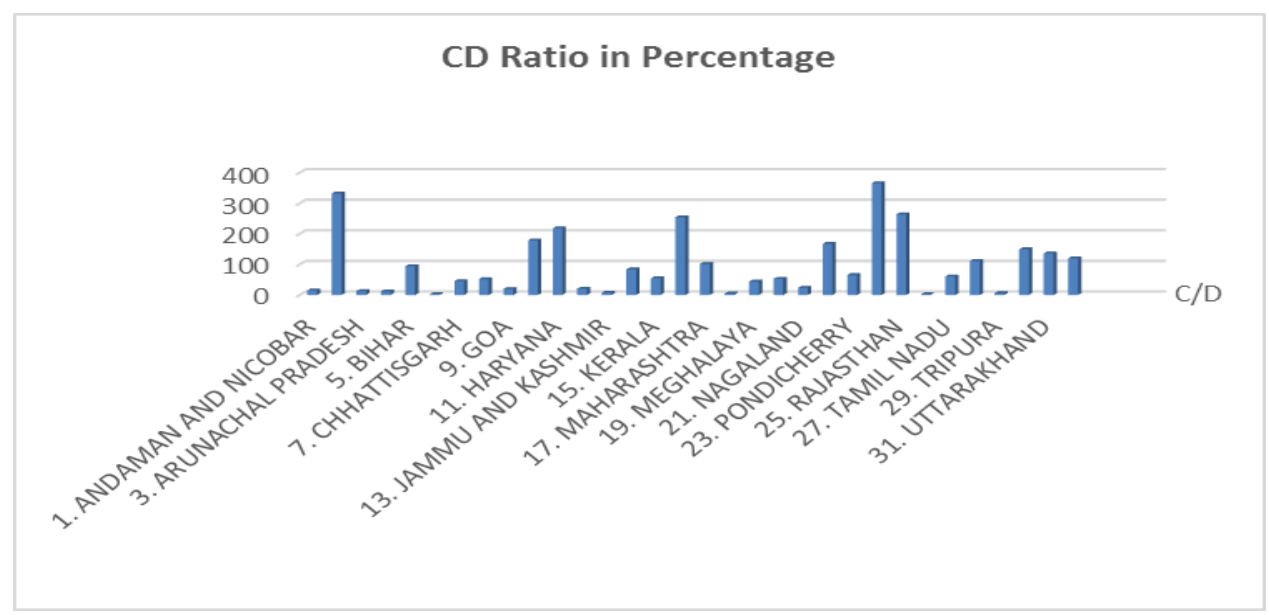

Fig No.2.Credit to Deposit Ratio

Overdue rate is the ratio of the amount of overdue loans to the total demand. Manipur has the highest overdue rate while

\section{Overdue and NPA}


Haryana has the lowest. Gross NPA is the ratio of absolute

NPA rate while Haryana has the lowest.

NPA to the total advances. Arunachal Pradesh has the highest

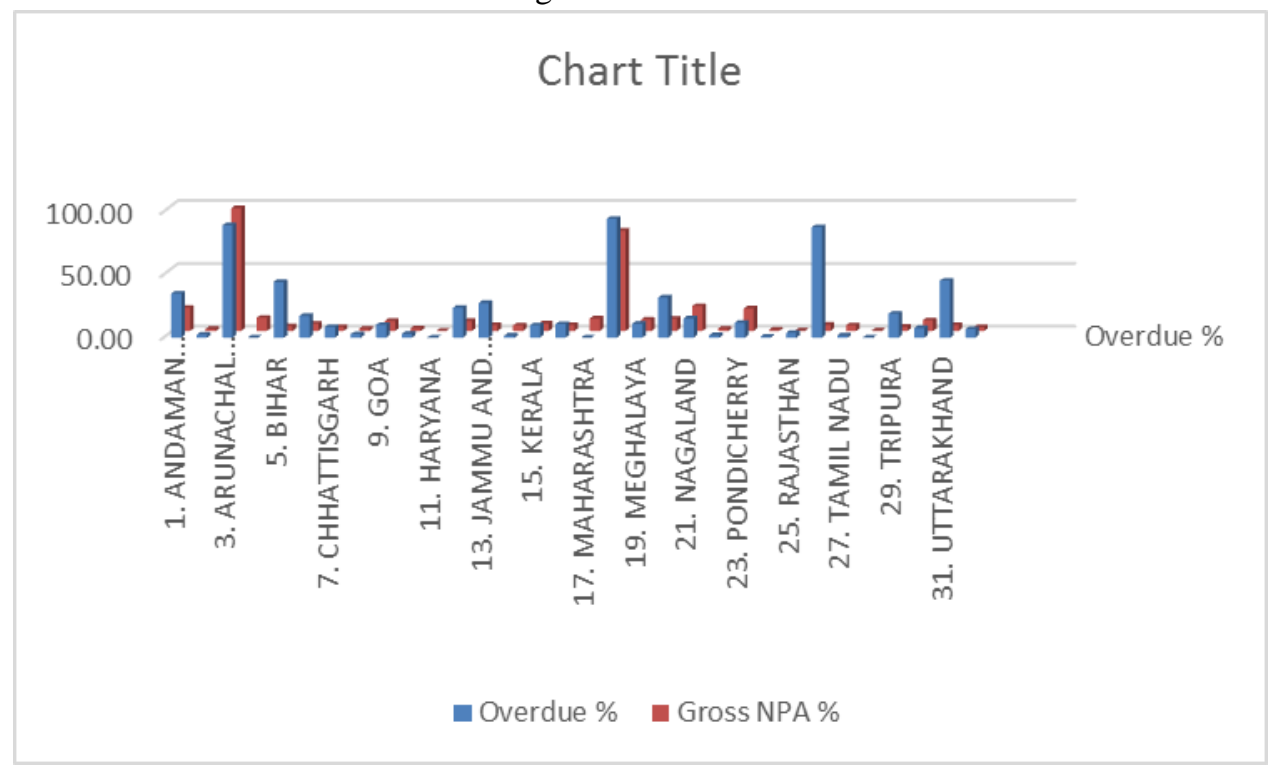

Fig No.3. Overdue \& Gross NPA

\section{Conclusion}

Financial assistance from Reserve Bank of India and National Bank for Agriculture and Rural Development (NABARD) are mainly routed through the state co-operative banks and hence they have to ensure more efficiency in their lending operations. The study has revealed higher deviations in efficiency scores among state co-operative banks. The overdue rate and Gross NPA of a few banks are at an alarming rate. A negative correlation has been observed between efficiency and overdue; and efficiency and NPA. Hence working on the inefficiencies can improve their overdue and NPA rate. They are the apex co-operative institutions in the state and their performance will have an impact on the entire co-operative credit structure in the state.

Co-operatives are member driven and democratic in nature and played a pioneering role in providing agricultural credit to a very large rural population especially in remote areas. In a country like India, where there is a huge disparity in income distribution, the ideologies of co-operation are highly essential. Even now co-operative credit institutions are highly significant in rural areas to prevent the exploitation of the private money lenders and for promoting financial inclusion. Kerala, the most literate state in India, has a higher reliance on these institutions with more than $60 \%$ of its population are the members. These institutions are also engaged in many social, health care and educational activities in the state apart from the promotion of agriculture.

The problems and challenges of SCBs differ from state to state. A few banks like West Bengal, Pondicherry, Sikkim have problems in deposit mobilisation and hence running on borrowed funds which incur high cost for funds while in some state, banks are flooded with deposits and less demand for credit. Hence in every state, the management and the regulating authorities should work on transforming the co- operative credit system into a viable and self- sustaining system by identifying and addressing their own core inefficiencies. More researches have to be undertaken in these areas especially in bringing more professionalism and modernism in co-operative banking. Correcting the inefficiencies is a must for being profitable and sustainable.

\section{References:}

[1]. Banker, R., Charnes, A., \& Cooper, W. (1984). Some Models for Estimating Technical and Scale Inefficiencies in Data Envelopment Analysis. Management Science, 30(9), 1078-1092. https://doi.org/10.1287/mnsc.30.9.1078

[2]. Berger, A., \& Humphrey, D. (1997). Efficiency of Financial Institutions: International Survey and Directions for Future Research. SSRN Electronic Journal. https://doi.org/10.2139/ssrn.2140

[3]. Charnes, A., Cooper, W., \& Rhodes, E. (1978). Measuring the Efficiency of Decision-Making Units. European Journal of Operational Research, 2(6), 429-444. https://doi.org/10.1016/0377-2217(78)901388

[4]. Farrell, M. (1957). The Measurement of Productive Efficiency. Journal of The Royal Statistical Society, 120(3), 253-281. Retrieved 10 April 2020, from

[5]. Ganesan, N. (2006), "A study on the Performance Analysis of the State Co-operative Banks in India", Prajnan, Vol. 34, No. 4, pp. 311-321.

[6]. Gaurav, S., \& Krishnan, J. (2017). How Efficient are India's Co-operative Banks? Evidence from DCCB's. Economic \& Political Weekly, LII(12), 
115-124. Retrieved 27 March 2020, from

[7]. International Co-operative Alliance | ICA. Ica.coop. (2020). Retrieved 2 April 2020, from https://www.ica.coop/en.

[8]. Jayaraman, A. and Srinivasan, M. (2009). Relative efficiency of scheduled commercial banks in India (2001-08): a DEA approach. Prajnan, NIBM Pune, XXXVll1(No.2), pp.111-126.

[9]. Lin, T., Lee, C., \& Chiu, T. (2009). Application of DEA in Analysing a bank's operating performance. Expert Systems with Applications, 36(5), 88838891. doi: 10.1016/j.eswa.2008.11.018Elsevier BV

[10]. Lovell, C., Grosskopf, S., Ley, E., Pastor, J., Prior, D., \& Vanden Eeckaut, P. (1994). Linear programming approaches to the measurement and analysis of productive efficiency. Top, 2(2), 175248. https://doi.org/10.1007/bf02574810

[11]. National Federation of State Co-operative Banks. (2019). Basic Data of State Co-operative Banks. Mumbai.

[12]. Rakshit, D., \& Chakrabarti, S. (2012). An empirical analysis of the factors influencing the financial performance of an Apex Co-operative Bank: A Case Study. The Management Accountant, 47(2), 197-200. Retrieved 14 April 2020, from.

[13]. Ramanathan, R. (2003). An Introduction to Data Envelopment Analysis. Sage Publications, New Delhi.

[14]. Reserve Bank of India, 2000. Report of The Task Force to Study the Co-operative Credit System and Suggest Measures for its Strengthening. Mumbai.

[15]. Roy, C., \& Das, S. (2013). Cost and Revenue Efficiency of State Co-operative Banks in India: Evidence from North-East using Data Envelopment Analysis. (A Journal of National Institute of Bank Management, Pune, 35(4), 32-54. Retrieved 14 April 2020, from. 